Article

\title{
Corporate Social Responsibility at LUX* Resorts and Hotels: Satisfaction and Loyalty Implications for Employee and Customer Social Responsibility
}

\author{
Haywantee Ramkissoon ${ }^{1,2,3, *(\mathbb{C})}$, Felix Mavondo ${ }^{4}$ and Vishnee Sowamber ${ }^{5}$ \\ 1 College of Business, Law \& Social Sciences, Derby Business School, University of Derby, \\ Derby DE22 1GB, UK \\ 2 School of Business \& Economics, UiT, The Arctic University of Norway, 1621 Alta, Norway \\ 3 College of Business \& Economics, Johannesburg Business School, University of Johannesburg, \\ APB 17011 Johannesburg, South Africa \\ 4 Department of Marketing, Monash Business School, Clayton Campus, Monash University, \\ Melbourne, VIC 3000, Australia; Felix.Mavondo@monash.edu \\ 5 Faculty Research Centre for Financial and Corporate Integrity, Coventry University, Coventry CV1 2TU, UK; \\ sowamberv@uni.coventry.ac.uk \\ * Correspondence: H.Ramkissoon@derby.ac.uk
}

Received: 12 October 2020; Accepted: 17 November 2020; Published: 22 November 2020

check for updates

\begin{abstract}
Corporate Social Responsibility (CSR) remains a hot topic in management. Yet, little is known about how well managers, employees and consumers are responding to CSR initiatives to align with the 2030 Agenda for Sustainable Development. Underpinned by well-established theories, this study develops a single integrative model of managers', employees' and consumers' CSR. Data were collected from the LUX* group of resorts and hotels located on three Indian Ocean islands: Mauritius, Reunion and the Maldives. Structural equation modelling was employed. Findings reveal: (1) organizational CSR is positively related to employee social responsibility; (2) organizational CSR is negatively associated with customer social responsibility; (3) employee social responsibility is negatively related to customer social responsibility; (4) employee social responsibility is negatively related to customer delight; (5) customer social responsibility is positively related to customer satisfaction; and (6); customer social responsibility is positively related to customer delight. Strategic CSR initiatives with a multi-stakeholder engagement approach are discussed.
\end{abstract}

Keywords: corporate social responsibility; stakeholder engagement; employee; customer satisfaction; loyalty; post COVID-19 implications

\section{Introduction}

Research on environmental and social corporate social responsibility (CSR) have attracted significant attention. However, an integrated model with managers', employees' and consumers' approach to CSR initiatives to align with the 2030 Agenda for Sustainable Development is yet to be established. The United Nations Global Compact, a UN initiative, created in 2000, was introduced to engage multinational organizations and corporations to spot and evaluate their CSR activities. The initiative strives to advocate the inclusion, monitoring and reporting of the UN SDGs into their business operations [1]. With the 17 Sustainable Development Goals (SDGs) at the core of the Agenda, the objective is to collaborate to solve development challenges to balance economic, social and environmental sustainability contributing to identified priorities [2].

This needs to be done through diversity, inclusiveness, shared values and collaboration with key stakeholders including civil society and policy makers [3,4]. The United Nations proclaimed 2017 as 
the International Year of Tourism for Sustainable Development emphasizing the importance of this sector and its ability to contribute towards the achievement of some of the SDGs. The Travel and Tourism industry experienced growth in terms of GDP until the COVID-19 dramatic impact on global businesses [5]. Prior COVID-19, however, there was still growing concern regarding the contributions to SDGs. Examples include inequalities such as what is being done to ethically integrate marginalized people for them to benefit from tourism [6]. Revenue leakages and gaps have been observed [7]. Other examples include low remuneration for the number of hours worked [8], job insecurity [9], poor work-life balance [10] and emotional labor [11] resulting in low job satisfaction and high employee turnover in the tourism and hospitality sector [12]. Critics have described CSR as "hot air" or "corporate waffle" [13] fueling further research into its practices [14,15]. This required organizations to think of new strategies and business plans to operate successfully along with delivering benefits to the broader society.

Environmental reporting has been well established [16,17]. There is now growing focus on social impact of CSR and social reporting $[18,19]$. Literature evidences that despite the exigencies of the sector, employees who are taken care of by their employers tend to be more committed [20,21], which in turn increases customer satisfaction [22]. This shows that CSR plays a very important role in value creation [23]. CSR in tourism primarily focuses on advanced economies [24]. This demands more research in developing countries including small island developing states [25] to understand the phenomenon.

Considering the pivotal role of employee interaction with customers in service encounters [26], this study explores the nexus of relationships between the three groups to achieve marketplace goals for firms in the tourism industry. The present study is based on data collected at LUX* Resorts and Hotels, a 5-star Mauritian company with luxury resorts operating in several destinations in several countries. The study examines the relationship of organizational CSR initiatives and their impact on employees' CSR and its ultimate influence on customer social responsibility and finally on customer satisfaction and delight. CSR is used as an umbrella concept, which incorporates four major facets of company sustainability policies and activities, aimed for community stakeholders, employees, customers and government [27-29].

Our study's objectives and contributions are: (1) we develop and test a single integrative model exploring the pattern of interaction and influence between three dynamic forces: the organization, its employees and its customers, from a CSR perspective in tourism and hospitality, (2) we contribute to CSR studies using a multi stakeholder development approach across five-star resorts in small island developing states.

\section{Literature Review}

\subsection{CSR in Tourism and Hospitality}

The increasing awareness of environmental impacts of travel and tourism paved the way for adopting CSR principles that are congruent with social norms and expectations of good citizenship practices for firms in the tourism and hospitality industry [30]. This has generated the need for a clearly identified connection of firms' Corporate Social Responsibility (CSR) initiatives with its internal and external stakeholders. Managers recognize CSR and sustainability strategies are not just arbitrary altruistic acts but are "essential" business imperatives for their strategic market operations, innovations in customer interaction and even for the internal talent management [31]. Despite continual debate on precise policies of CSR in the industry, its practice has grown among both practitioners and researchers worldwide. Most of the firms in the travel, tourism and hospitality industries if not all, started practicing various CSR activities. Levy and Park (2011) identified 129 CSR activities adopted by ten prominent hotel chains i.e., those having the largest number of rooms in the world.

Firms operating in tourism and hospitality sectors are not homogeneous in terms of adoption of their CSR policies and practices. Moreover, with its characteristics of intangibility and variability 
in its services [32], tourism offers can make their brands "tangible" by ensuring brand-customer identification [33] based on good corporate citizenship [34]. For eco-tourism companies, more ethical and social components are integrated into their businesses [35-37].

CSR continues to attract importance in the travel, tourism, and hospitality industries in view of its adoption of sustainability strategies [38-40]. The focus has been on internal marketing issues, employee perspectives [41,42], business sustainability [43,44], influence on critical service process [45] and consumer preference, as well as business ethics and shared value [46] among others.

A PricewaterhouseCoopers' (PWC) survey of CEOs found that the latter intend to give more importance to CSR (PWC, 2011). More than $25 \%$ of Fortune 500 companies provide visibility on their environmental, social and sustainability commitments. The private sector is paying more and more attention to CSR and inclusiveness [47]. The service-profit chain model [48] illustrates that employee attitudes and behavior as well as customer satisfaction, delight [49] and loyalty in service industries are ultimately linked to firm profit. Organizational CSR establishes the enabling corporate culture for employee CSR practices. CSR promotions to the external marketplace establishes firms' citizenship image among customers [50] whereas internal marketing establishes the acceptability and participation of its employees to firms' CSR initiatives. The ultimate goal for the firm is to strengthen the corporate citizenship image.

\subsection{Organisational CSR and Internal Stakeholders}

A pool of research focused on the positive associations between organizational CSR and employee attitudes [51-54]. Several studies have also shown that consumers have positive evaluations for companies demonstrating CSR activities [55,56]. A number of studies have noted negative relationships between organizational CSR and consumers' CSR attitudes $[57,58]$ when companies are more concerned with their firms' interests than with greater public interests. These inconsistencies demand for more research in the field $[59,60]$.

CSR research has been underpinned by "theory of reasoned action", the "theory of planned behavior", "social identity theory" and "stakeholder engagement theory" in a number of studies exploring links between CSR, employee attitudes and related impacts on the organization [61]. The theory of reasoned action predicts an individual's behavioral intentions in engaging in a specific activity is associated with one's attitude and subjective norms. The theory of reasoned action [62] and theory of planned behavior [63] are extensions of the former and have been applied in various CSR studies $[64,65]$. Several CSR studies for example [66,67] have also drawn on social identity theory [68]).

Tourism has been increasingly contributing to significant global environmental change, notably climate change [69,70], biodiversity loss, land-use change, water use and invasive species [71,72]. International tourist numbers have been estimated to reach 1.8 billion by 2030 [73]. This means there will be even greater need for businesses to cater for this increase and if unmanaged, it will result in dire consequences for public and environmental health. Tourism has often been conceived as essentially pure marketing, as it is often based on packaging existing resources and assets of a destination, and subsequent promotion to new markets [74] without much consideration for the deleterious impacts it often brings along if not carefully managed [75].

The growth in tourist numbers until the COVID-19 health pandemic had forecasted an increase in negative environmental impacts if tourism operators were to continue to follow a "business as usual" path $[76,77]$. If there were to be no change, energy consumption was expected to increase by $154 \%$ greenhouse gas (GHG) emissions by $131 \%$, water consumption by $152 \%$ and solid waste disposal by $251 \%$ [78]. The planet cannot sustain the current levels of consumption with its current carrying capacity. According to Met Office (2017), the year 2016 was officially reported as the warmest year on record. It was mentioned that the El Niño event was partly responsible but the main cause to global warming is human activities from increasing greenhouse gases in the atmosphere [79].

The global pandemic COV-SARS-2 has emphasized the climate change crisis; we need sustainable and urgent measures in place for the post pandemic economic structure. COVID-19 has had a 
tremendous halt on tourism and hospitality businesses [80], there will be an even greater need for responsible behaviors as business slowly starts getting back to normal [81]. Researchers argue that this could be a long-term process; hospitality businesses need to continue with a multi-stakeholder engagement approach [82] to generate collective benefits for the tourism and hospitality industry. There is further need for businesses to work more closely with governments as they have a more exponential influence on resources [83]. Firms are legislated to do so through good governance and ethical practice requirements. Fortunately, organizations do not engage in CSR initiatives solely because of compliance. The actions are triggered due to other factors such as demand for environmental and community friendly products and services and responsible management expectations by investors and other key stakeholders. This is likely to become more pronounced with consumers' collective efforts to become more pro-environmental [84] due to perceived threats of detrimental impacts of human activities on the environment and fear of a second wave of COVID-19 [85]. There are also other key benefits such as cost reduction and increased profitability [86].

The current global health crisis and climate change concerns clearly reinforce the need for businesses to align with sustainable development goals [87]. To promote behavioral change in a target audience in order to engender public good, social marketing of organizations utilizes marketing techniques linked to same [88-90]. The growing demand from tourists for ethical and sustainable practices is an important motivating factor for CSR in business practices [91,92]. Another key factor is that there is a great concern for the protection of local environment and culture [93] and environmental reporting to satisfy legal requirements [94].

Often in organizations, top management initiates the establishment and growth of a corporate culture that emphasizes CSR which gradually shapes employee attitude and performance around CSR initiatives [95]. As a social control system, the corporate culture can determine internal stakeholders' commitment and performance [96] through greater appreciation for socially appropriate norms [97] of business interaction. Moreover, when an employee perceives the strategic fit between his/her personal identity and firm's characteristics [98], they are likely to behave collaboratively to achieve the firm's CSR goal [99,100].

CSR initiatives of hospitality firms endorse greater trustworthiness for the intangible nature of service transaction, and this demands solid evidence to establish their accountability [101]. Firms, hence, create and retain the corporate culture of shared values among different levels of management to facilitate CSR activities to achieve their greater CSR goals effectively [102]. Companies often leverage their CSR strategies to attract and retain quality skilled employees and use this as a competitive advantage [103]. The key is for management to maintain a more holistic perspective, recognizing that employees identify with the firm, not only through efforts to save the natural environment, but also through those pertaining to community, employees, and customers [104]. As internal stakeholders, when employees have a clear vision of their organizations' CSR, they tend to accept and institutionalize these initiatives [105]. For service firm employees, every step of the service design and delivery are influenced by this corporate culture [106]. Drawing on social agency theory [91], employees' identity is influenced by their employers' social image, that is, the firm's accountability and responsible dealings with their stakeholders. Employees feel proud to contribute to the community. The employers' CSR programs often motivate employees to invest their time and effort for community benefits [107]. Employees' CSR performance is about the affective commitment and compliance one makes with the company's strategic initiative of CSR implementation. A service firm's CSR activities through their employees' performance, reflects the firm's characteristics to project their social citizenship [106].

Literature evidences a number of studies investigating CSR customer behavior [108-110]. The prevailing and rapidly changing COVID-19 and climate change contexts call for urgent actions to protect human and planetary health. The customer, as a member of the larger community holds the public view on corporate performances and CSR initiatives. Drawing on the social identity theory [111], we can argue that to build a distinct social identity and enhance their self-esteem, customers prefer and patronize service providers that are perceived as socially responsible. The resulting brand image from 
CSR efforts plays an important role in attracting a segment of already socially aware customers [107]. The fit between a company and its CSR activities exerts an authentic effect on corporate image [112].

Customers' own sense of social responsibility and fit between company performance and customer expectation can bring success in business. Customers may perceive a firm's CSR initiatives as a promise to perform and deliver services in a socially acceptable way [113]. This may even generate a halo effect in other areas of firms' operations [114]. The rise in customer expectation due to firms' external CSR communication may have mixed effects on developing customer perception. Different CSR initiatives may favor customer satisfaction or other purchase decisions differently [115].

Some evidence in literature suggests that consumers found less trustworthiness in promotion-based CSR activities than the institutional implementation of CSR programs [116]. For a service firm, external communications make overt CSR promises [113] and corporate CSR culture in service delivery complements to fulfil customers' social responsibility expectations. A combination of corporate CSR initiatives, especially awareness campaigns and cause-related marketing activities can contribute to customer education; whereas, environmental and citizenship initiatives at the service point-of-sales affirm customers' social responsibility.

\subsection{Employee CSR and Customer Engagement}

The more engaged an employee is, the more efficient and hard-working he/she is [117] (Karatepe, 2013). This in turn has a positive impact on service quality for customers [118] (which impacts on customer satisfaction and loyalty [119,120]. Research shows that CSR is positively associated with organizational commitment $[67,121]$. CSR plays an important role in enhancing companies' reputation as an ethical business [122]. Organizations from different fields show different "responsibility profiles". Some sectors prioritise environmental protection, while some show more concern towards economic or social responsibilities [123]. It can also be observed that in developing countries, the political challenges play a role in shaping the practice of CSR [124]. This is evidenced by CSR awards promoted by tourism organizations for those located in emerging economies who are investing more efforts in social and economic sustainability. The CSR awards often demonstrate they have successfully implemented various initiatives in line with education, health and youth community development [125].

Managing risks and building reputation have been shown to be the key motivators for business CSR [126]. In parallel, CSR initiatives enhance the employees' organizational identification. This in turns increases employees' loyalty [112] and employees' trust and job satisfaction [105]. Some evidence [127] shows that employee engagement is positively related to their involvement in organizational Human Resource Management (HRM) e.g., in CSR-inspired initiatives such as environmental protection.

CSR may enhance leadership skills and motivation for employees who like to participate in CSR projects [128]. Studies show that engaging in CSR practices is very beneficial. It mitigates risks, establishes a legitimacy, builds good reputation, attracts employees and increases customer satisfaction $[126,129]$. There is a paucity of studies investigating the relationship between company induced employee CSR and its direct or indirect outcomes, in terms of generating greater customer satisfaction and delight. In contrast, there is growing evidence suggesting that general employee attitude and behavior at the critical interaction moment with customers, essentially influence customer perception of the organization, its offers and quality of services [130]. Employee CSR can be defined as the derivative of the compliance of company employees to the company CSR initiatives. In most cases, proper orientation makes employees comfortable with the firm's culture and proper internalization of corporate initiatives, leads to higher level of affective commitment and eventual decrease in turnover intention [42]. Although firms cannot expect an instant financial outcome, employees' CSR engagement and performance can accrue long-term economic benefits [131] from attractive workplace conditions [132], improved employee morale and commitment [133], and thus, a congenial environment for better customer relations.

For front-line employees, attaining customer desire demands an assessment of customers' perception about the company, even beyond the company's immediate offer [134]. CSR initiatives, 
offers, and events have become a relatively common conversation element for employees while communicating with customers that creates a window into the innermost values of the customers and thus, facilitates the social comparison between them [135] Relational identity [111] suggests that customers may identify company employees as members of the same social category or having similar fellow feelings toward the society when they come across company's corporate culture of employees' CSR performance at the service encounter. Employees who identify with customers consider themselves to belong to a common social group with customers [111]. Employee-customer identification goes beyond attitudes about customers or their perceived traits, reflecting their commonalities in terms of social orientation [134].

Corporate social responsibility has become a relatively common element in communicating with customers, with numerous ways in which an employee can develop beliefs about customers' CSR perceptions. Social responsibility activities can stimulate social comparison and social categorization, because such activities are often interpreted as a meaningful indication of a person's values [135]. Employees may interpret customer perceptions about the company's CSR to better understand their character.

At least three distinct research streams have been identified to establish the link between company CSR and customer satisfaction. Firstly, the stakeholder theory proposes that while caring about their own consumption experience, customers also care about firms' actions that have potential to enhance stakeholder value [136]. Secondly, company CSR performance record, if communicated effectively, creates a context for consumers' favorable evaluation of the firm [137] and increasing their level of support [138]) as they identify themselves with the company. It is likely that customer-company fit brings satisfaction for customers $[139,140]$. Third, customers' higher perceived value from firms' CSR activities, consequently, acts as an antecedent to higher satisfaction from transacting with a socially responsible company [136]. Such activities indicate greater customers' satisfaction.

Employee welfare is influenced by CSR; there is an increased commitment in CSR among international hotel chains [91,95]. Within the domain of CSR, a stream of research is gaining strength with more enlightened academic views on Personal Social Responsibility (PSR), realizing a firm's dependence on its employees' personal sense of responsibility [141]. In the services organization e.g., in the tourism and hospitality industry, where several boundary spanning roles determine the success of customer interaction [142], PSR may play an important part to portray strong citizenship messages though employees' personality disposition [143]. In the organizational CSR discourse, PSR puts the employees and their personal traits at the core [141]. Individuals acknowledge the societal and environmental consequences of one's own actions [144]. Surprisingly, the concept of employees PSR, its aspects and its sensitivity at the time of dealing with customers has received little attention in the hospitality or tourism literature [143] although employees' personality traits have long been acknowledged [145].

Based on their own life experiences and level of social justice awareness [143] employees often form their own perception to decide about the management's fairness with CSR programs that eventually trigger their behavioral responses in everyday life [105]. Research identifies values such as altruism and conscientiousness as employees' helping behavior [130], which can be the reflection of their personal sense of responsibility and good citizenship behavior. The presence of personal responsibility and social orientation makes it easier for employees to actively engage in CSR activities of their firms [143]. An employee's responsibility disposition is basically the sum of his/her cultural background, personal values and the company's ethical training [146]. Employees, performing as boundary spanners, come across company customers, interacting with them to generate service experiences. During such encounters, employees' representation of social responsibilities while presenting the company and its brand is not purely "corporate", a large part of it is explainable as attributed from individual characteristics [146].

Employees today are looking for jobs that are exciting, challenging and at the same time have a good fit with their own perception of fairness and justice [112]. Compliant employees' CSR performance 
is the reflection of their firms' CSR influencing their attitudes and behavior, which in turn influence consumers' evaluation of service quality, value, and satisfaction [147-149]. An investigation of how hospitality industry employees' CSR activities influence their attitudes at work, and their potential influence on customer satisfaction through quality customer interaction is warranted, to better evaluate customers' satisfaction from tourism experiences [100]. Notably, employees' CSR performances are also becoming more diagnostic of firms' real CSR initiatives. Heightened self-esteem encourages employees to contribute to their company by serving customer needs, as a key company success indicator [134], that results in greater customer satisfaction.

Most importantly, companies are to perform their service dependably, and reliably to their customers [142]. Customer judgment about the service performance can produce a pleasurable level of fulfilment, thus "satisfaction" from their intangible service consumption. As firms' CSR creates a positive impact on customer satisfaction [150], employees' CSR performance can enhance the quality of customer interaction at its functional level. However, when companies focus on firm serving motives leading to skepticism towards CSR, customer satisfaction is not achieved $[59,60]$.

Although scholars and industry practitioners have sought to identify the relationship between firms' social responsibilities and customers' satisfaction, findings remain inconclusive. An extant review of the literature suggests that there may be a positive relationship between CSR initiatives and consumer outcomes [150].

Customer delight has been considered as a performance goal based on customer response [49] based on disconfirmation of their service experience from marketing organizations [120,151]. Customer delight has been conceptualized as an emotional response of customers from what is captured by measuring customer satisfaction and can be another distinct performance metric [152]. While customer satisfaction can be earned by delivering according to customer expectations [153], customer delight only can be achieved through exceptional services. Exceptional boundary spanners in direct contact with the customers are the face of the company to bring success in customer delight $[154,155]$.

Although some, for example [156] argue that surprise is not essential to make customers delighted, most research in this stream mandates [151] surprise as a significant element to produce customer delight which creates a dilemma for all customers and loyal customers in specific. However, providing a delightful surprise has a definite impact on loyalty intention and generates positive word-of-mouth [157]. In a tourism and hospitality setting, where the customer encounter is characterized by infrequent and non-repetitive holiday experiences, greater opportunities are available to make the guest delighted relating to multiple aspects available in the destination [158]. The relationship between employees' CSR performance and its impact on the customer delight is yet to be further explored. However, as the significant correlation between positive affect (interest and joy-components measuring customer delight) and satisfaction has been observed [159], it can be argued that customer delight is the progression of customer satisfaction. So, similar forms of relationship between employee CSR and customer delight can be observed between employee CSR and customer satisfaction. The hospitality industry is characterized by high turnover rates and the increasing customer demand that can only be served by retaining exceptional, self -motivated employees at boundary spanning roles [155].Empowerment, involvement of employees in CSR initiatives and improving morale by taking part in a firm's CSR can act as a job motivator for employees. Motivated and committed employees usually show loyalty and great potential to deliver service [20] and customer delight. Another argument could come from increasing blame for businesses for worsening the social justice and natural environmental balance by the community and citizens. If customers realize businesses' CSR initiatives as coming across through company employees caring about the social responsibility issues, it may add to their "surprise" and increase the occurrence of a delighted situation.

The role of company employees, especially their personal social responsibility to generate customer delight is yet to be explored. Referring to our earlier discussion, as boundary spanners, employees' social responsibility orientation being supported by company CSR culture, is expected to generate customer satisfaction $[134,150]$. The surprise component in satisfaction can only be earned 
through extraordinary service experiences [157]. Creating an "extraordinary" service experience for the customer requires firms to rely on exceptional surface traits such as empathy, high degree of responsiveness to anticipate and meet customer needs and a strong drive to please them [154]. This requires working really hard, even pushing the boundary of the company service blueprint. Managers cannot expect their employees having such exceptional surface traits without ensuring their altruism and conscientiousness; those largely come from their socially responsible behavioral formation [130].

Customer satisfaction and delight mostly come from non-ordinary time, at an uncommon place, encouraging customers to express a release from their regular value system $[49,143]$ while others are still firmly within their values. Although it is recommended to have a break and enjoy the delight [160] for boundary spanners it is a challenge to give the customers experience of delight moving beyond so-called subterranean values. In this particular situation, employees' personal integrity, sense of responsibility and humanity are much sought after traits for employers.

From the extant review of the literature we develop and propose our conceptual framework illustrated in Figure 1.

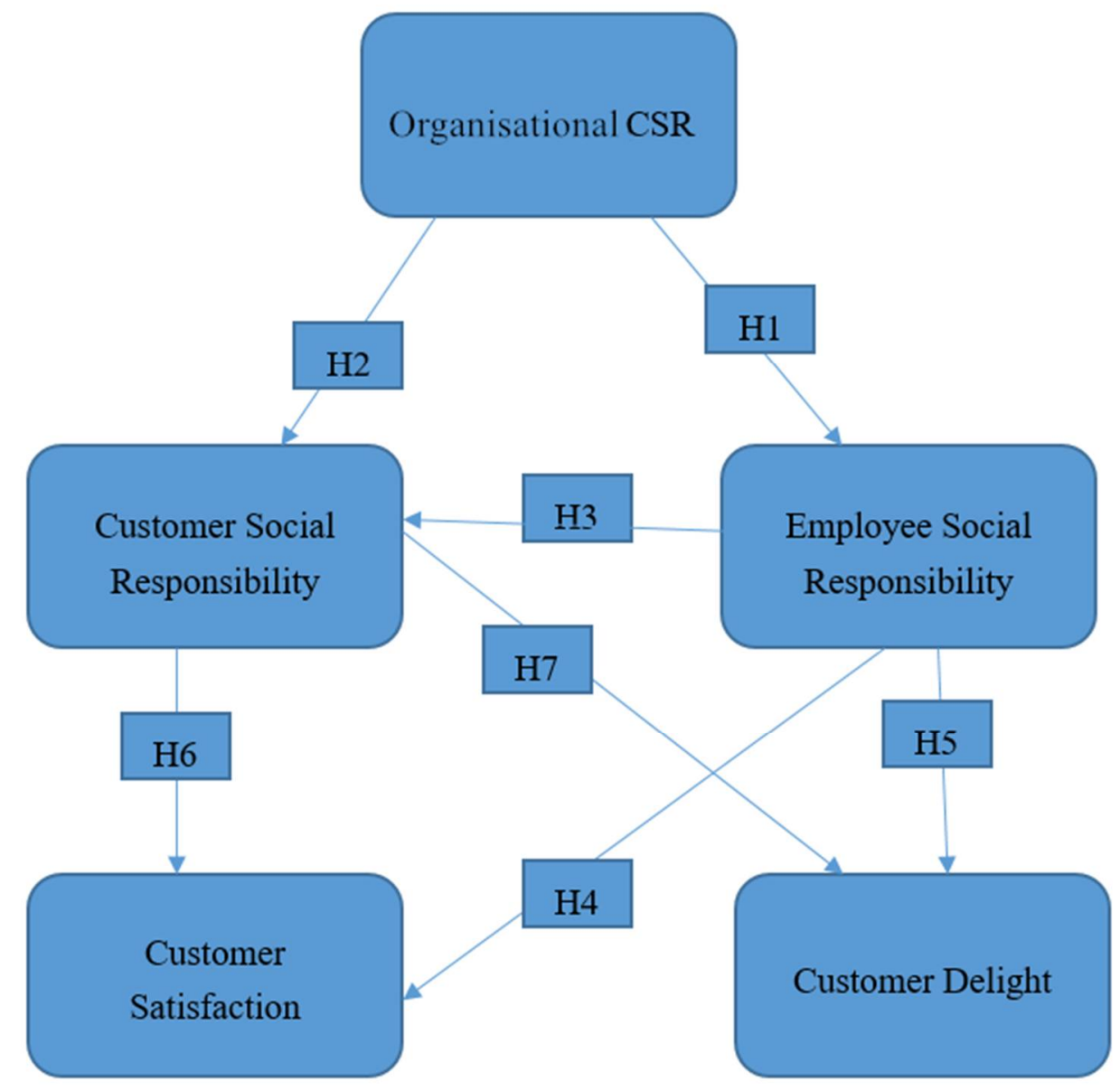

Figure 1. Conceptual Framework.

We propose the following hypotheses:

Hypothesis 1 (H1). Organizational CSR is positively related to employee social responsibility.

Hypothesis 2 (H2). Organizational CSR is positively related to customer social responsibility.

Hypothesis 3 (H3). Employee social responsibility is positively related to customer social responsibility. 
Hypothesis 4 (H4). Employee social responsibility is positively related to customer satisfaction.

Hypothesis 5 (H5). Employee social responsibility is positively related to customer delight.

Hypothesis 6 (H6). Customer social responsibility is positively related to customer satisfaction.

Hypothesis 7 (H7). Customer social responsibility is positively related to customer delight.

\section{Methodology}

\subsection{Study Context}

Data were collected from, employees and customers across $3 \mathrm{LUX}^{*}$ resorts in 3 distinctive Indian Ocean islands of Mauritius, Reunion and the Maldives. LUX* is a Mauritian hotel group with luxury resorts also operating in China and other forthcoming ones in Europe and Asia-Pacific. The hotel industry in the Indian Ocean islands have developed rapidly over the past years, largely as a result of it being one of the industries initially opened to foreign investments. However, the islands are very fragile; CSR efforts are important to mitigate negative social and environmental impacts [161,162]. This will help with the industry's contribution to sustainable tourism for broader societal goals $[28,163,164]$.

The LUX* group of resorts has received numerous awards including Corporate Reporting Award in Integrated Reporting by PWC (PricewaterhouseCoopers), various awards at the International Hotel Awards: "Best Large Hotel Mauritius", "Best Sustainable Hotel Mauritius" and "Best Sustainable Hotel Africa", through its CSR initiatives "Tread Lightly by LUX" and "Ray of Light by LUX". LUX* is also the first hotel group listed on the Stock Exchange of Mauritius Sustainability Index and its resorts are certified Gold Travelife Sustainability. In addition to its resort development, LUX* operates a private islet "Ile des Deux Cocos" in Mauritius with renewable energy Solar system. The group's objective is to review its energy mix to include more renewable energy solutions.

\subsection{Scale Measurements}

Measurement scales on a 1-7 Likert scales were borrowed from well-established studies in literature $[49,105,136]$ and adapted to the context of our study. Some examples of items borrowed from the literature are: LUX encourages employees to join civic organizations that support the community; LUX encourages partnerships with local businesses; LUX gives adequate contributions to charities; employees view themselves as partners of LUX; at LUX all employees commit to organizational goals. The questionnaire was reviewed by academics in hospitality and tourism for face validity. The questionnaire was further revised following their suggestions to ensure ease of communication [165].

\subsection{Sample and Data Collection}

Management and employees at the LUX resorts were sent the questionnaire and requested to participate in the study. The data collection was effected in 2016; the questionnaire was distributed through the Human Resource Departments. Completed questionnaires were deposited at central collection points. Respondents were assured of complete privacy. The greater the participation the more likely the greater representativeness of the sample. Studies show that CSR activities are better understood theoretically and tested empirically when they are organized by stakeholder types [121,166]. Firstly, questions were included in order to select front line employees, that is, those who are in direct contact with the guests during service delivery. Then employees who are in managerial positions were also requested to provide their perceptions. Thirdly, a sample of hotel customers was surveyed with a questionnaire that was distributed by the receptions. This was a shorter questionnaire to solicit larger response rate. Their responses were used as the dependent variables of interest to this study to minimize CMV. Structural Equation Modelling (SEM), a robust statistical technique [167,168], 
was employed to test the hypotheses. The measurement and the structural models were tested. The structural component of SEM tests the hypothesized relationships [169].

The sample for the analysis was 436 . This was the smallest of the three categories of respondents i.e., managers and supervisors. There were more frontline employees, but only 436 were randomly picked for this data analysis. There were more customers (650) and a random sub-sample of 436 was picked. The three categories had to be equal to avoid missing values and the problems presented by analyzing unequal sample sizes in AMOS. The model had robust psychometric properties. Convergent and discriminant validity were established. The average variance extracted (AVE) were greater than 0.50 supporting convergent validity. The square root of AVE for each construct was greater than the correlations between latent constructs, thereby satisfying the discriminant validity criterion [170] (see Table 1).

Table 1. Correlation, square root of AVE and Reliability.

\begin{tabular}{lccccc}
\hline & $\mathbf{1}$ & $\mathbf{2}$ & $\mathbf{3}$ & $\mathbf{4}$ & $\mathbf{5}$ \\
\hline 1. Management CSR & $\mathbf{0 . 6 8 9}$ & & & & \\
\hline 2. Employee CSR & 0.043 & $\mathbf{0 . 6 5 2}$ & & & \\
\hline 3. Customer Social Responsibility & $-0.133^{* *}$ & $-0.156^{* *}$ & $\mathbf{0 . 7 1 2}$ & & \\
\hline 4. Customer Satisfaction & 0.084 & $-0.194^{* *}$ & $0.840^{* *}$ & $\mathbf{0 . 6 9 3}$ & \\
\hline 5. Customer Delight & 0.028 & $-0.126^{* *}$ & $0.310^{* *}$ & $0.375^{* *}$ & $\mathbf{0 . 7 2 3}$ \\
\hline Internal Consistency & 0.848 & 0.818 & 0.864 & 0.788 & 0.768 \\
\hline Cronbach alpha & 0.828 & 0.812 & 0.864 & 0.803 & 0.667 \\
\hline Skewness & -1.069 & -0.733 & 2.485 & 2.576 & 2.376 \\
\hline Kurtosis & 1.015 & -0.646 & 2.285 & 2.844 & 2.226 \\
\hline
\end{tabular}

Note: ${ }^{*} p<0.05,{ }^{* *} p<0.01,{ }^{* * *} p<0.001$. Figures in bold on the diagonal are square roots of AVE.

We checked the robustness of the model following the approach by [171].

Robustness of model [171] uses the Chi-square difference between the SEM compared to the Measurement Model

$$
\begin{gathered}
\chi^{2}=621.779, \mathrm{df}=268 ; \mathrm{CMin} / \mathrm{df}=2.320 ; \mathrm{GFI}=0.990, \mathrm{AGFI}=0.878 ; \mathrm{NFI}=0.869 ; \\
\mathrm{TLI}=0.911 ; \mathrm{CFI}=0.920(\mathrm{SEM} \text { Model }) \\
\chi^{2}=619.035, \mathrm{df}=265, \mathrm{CMin}=2.336 ; \mathrm{GFI}=0.900 ; \mathrm{AGFI}=0.877 ; \mathrm{NFI}=0.870 ; \\
\mathrm{TLI}=0.910 ; \mathrm{CFI}=0.920 \text { (Measurement Model) }
\end{gathered}
$$

$\Delta \chi^{2}=2.744 ; \Delta \mathrm{df}=3 ; \mathrm{Cmin} / \mathrm{df}=0.915, p>0.90$ This suggests that the SEM is correctly specified, and the data fit the model very well. Thus, the discrepancy (i.e., Chi-square) is almost all accounted for by the measurement model. The path model fit statistics are robust suggesting no misspecification in the path model.

\section{Results and Discussion}

The sample consisted of mostly males for the managers (65\%). In total, $55 \%$ were females among the employees. In total, $52 \%$ were females among the customers. The majority of managers $(59.4 \%)$ and employees (55.6\%) have been working at LUX for a period of three to five years. The demographic profile is attached in Supplementary Materials.

The structural model is shown in Figure 2. Our findings (see Table 2) show that organizational corporate social responsibility positively influences employee corporate social responsibility. Hypothesis 1 is confirmed $(B=0.133 ; t=2.345 ; p<0.05)$. This finding is particularly illuminating in that it shows employees assimilate the organizational corporate responsibility to achieve organizational 
goals [99,100]. It also aligns with the social agency theory from [91] suggesting employees' identity is influenced by their employers' social image. Our findings further corroborate with [105] who suggest that when employees receive appropriate orientation, they tend to accept and institutionalize the organizational initiatives. This suggests that LUX* management has been able to communicate their corporate social responsibilities to the employees and the social responsibilities are well embedded in the organizational culture.

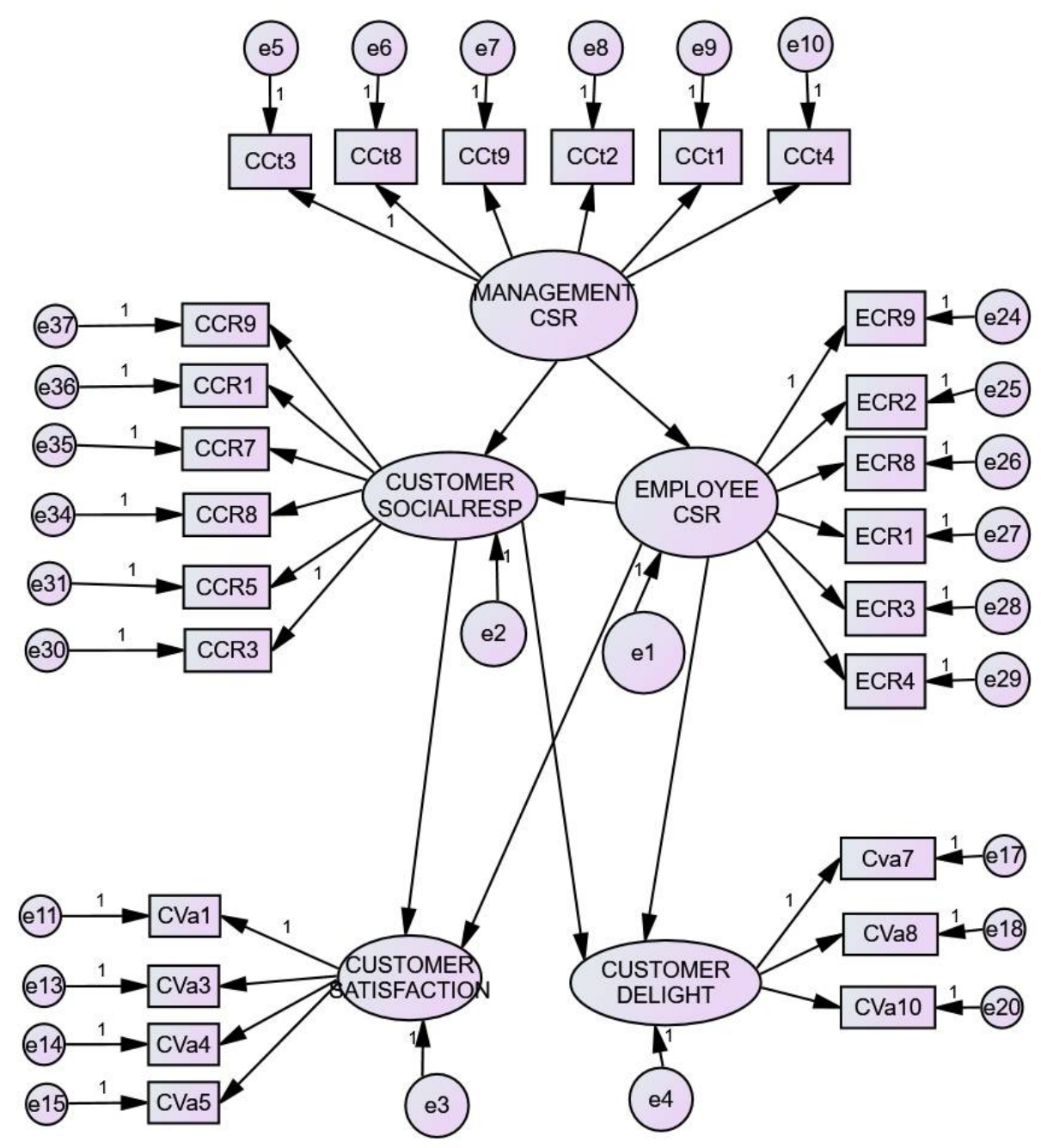

Figure 2. Structural Model.

Findings demonstrate that the relationship between organizational corporate social responsibility and customer social responsibility is negative and significant $(B=-0.144 ; t=-2.624 ; p<0.01)$, thus, H2 is not supported. Previous studies $[121,172]$ argue that CSR is positively associated with employee organizational commitment and plays an important role in enhancing companies' reputation as an ethical business. Organizational CSR, however, was found not to be a strong influencer of customer CSR $[173,174]$. Our findings suggest the need for LUX* to provide more subtle communication of its social responsibilities. Perhaps throwing in some incentives or redeemable points for future visits would be welcome. This finding raises interesting questions into the complex relations between tourists and the hotels they patronize. One gets the suspicion that tourists' sustainability concerns are one sided since the benefits are appropriated by the business without offering any tangible benefits to the visitors. 
Table 2. Results.

\begin{tabular}{lccc}
\hline \multicolumn{1}{c}{ Hypothesis } & $\begin{array}{c}\text { Standardized } \\
\text { Regression }(\beta)\end{array}$ & t-Value & $\begin{array}{c}\text { Supported/Not } \\
\text { Supported }\end{array}$ \\
\hline $\begin{array}{l}\text { H1: Organizational CSR is positively related to } \\
\text { Employee social responsibility }\end{array}$ & 0.133 & $2.345^{*}$ & Supported \\
\hline $\begin{array}{l}\text { H2: Organizational CSR is positively related to } \\
\text { Customer social responsibility }\end{array}$ & -0.144 & $-2.624^{* *}$ & Not supported \\
\hline $\begin{array}{l}\text { H3: Employee Social responsibility is positively related } \\
\text { to customer social responsibility }\end{array}$ & -0.182 & $-\begin{array}{c}\text { *.257 } \\
* * *\end{array}$ & Not supported \\
\hline $\begin{array}{l}\text { H4: Employee Social responsibility is positively related } \\
\text { to customer satisfaction }\end{array}$ & -0.024 & -0.727 & Not supported \\
\hline $\begin{array}{l}\text { H5: Employee Social responsibility is positively related } \\
\text { to customer delight }\end{array}$ & -0.0127 & $-2.134^{*}$ & Not supported \\
\hline $\begin{array}{l}\text { H6: Customer social responsibility is positively related } \\
\text { to customer satisfaction }\end{array}$ & 0.869 & $\begin{array}{c}12.430 \\
* * *\end{array}$ & Supported \\
\hline $\begin{array}{l}\text { H7: Customer social responsibility is positively related } \\
\text { to customer delight }\end{array}$ & 0.299 & $4.842 * * *$ & Supported \\
\hline
\end{tabular}

Note: ${ }^{*} p<0.05,{ }^{* *} p<0.01,{ }^{* * *} p<0.001$.

The situation is complicated by the circumstances of staying at resorts. Visitors may see this as a few days of breaking from their routines and house chores, a time where they can essentially relax. They may perceive that they have paid the full price for goods and services and they are entitled to use them. This problem is compounded by the practice of resorts of not demonstrating how social responsibility can improve the environment or future visitation. In some way resorts need "to walk the talk" [175]. People become cynical if talk is not matched by behavior. Customers may view that their social responsibility is not rewarded by improved services or lower prices or some combination of the two and engaging in socially responsible behavior is not overtly recognized or incentivized by the resort.

Our findings also suggest that employees' social responsibility is negatively associated with customer social responsibility ( $B=-0.182 ; \mathrm{t}=-3.257 ; p<0.001)$ thus, $\mathrm{H} 3$ is not supported. The suggestion is that visitors do not like to be pushed to take socially responsible actions during their vacation. This could have several interpretations. First, the nature of tourist visits is to seek relaxation and enjoy the holiday where someone else serves them [162] and not preach to them. Secondly, employees and customers are closely interacting and any apparent attitude suggesting the visitors are not behaving in a socially responsible manner may elicit a negative response from visitors. Third, perhaps it is a communication problem in that visitors may comply if the message is subtle or incentivized. Our findings and suggestions align with $[173,176]$ arguments that CSR might be effective in driving positive attitudes and behavior in theory but are rarely matched at the consumption stage. This demands that a consistent approach to CSR be firstly adopted by management and employees and appropriate messages are delivered to customers $[98,177]$ to trigger and promote the desired behaviors.

Hypothesis 4, proposing a positive relationship between employee social responsibility and customer satisfaction, was not supported $(\Omega=-0.124 ; t=-0.727)$. This suggests that $L U X^{*}$ needs to pay attention to consumers' views on CSR initiatives, this aligns with [178]. Consumers are one of the main stakeholders for hospitality businesses [179] and yet their voices are often ignored. Companies need to strongly emphasize how their CSR initiatives are beneficial to the needy [25] thus helping to achieve broader societal goals. Dialogue between employees, customers, the government and the local community will ensure a participatory approach and information exchange to ensure continuous evaluation, monitoring and feedback on CSR benefits to the community.

Employees' level of corporate social responsibility does not influence customer delight $(B=-0.127$; $\mathrm{t}=-2.134 ; p<0.05)$ thus, H5 is not supported. There does not appear to be a quid pro quo for customers to behave in a socially responsible manner. Organizational CSR practices might not provide the desired convenience to customers and hence can negatively influence customer delight. This reflects the need for organizations to consult with and engage the consumers to make them 
aware of the benefits of their CSR strategies and practices. Our findings suggest that LUX* needs to invest further in providing messages conveying the clear focus of personal and social benefits to make customers opt for sustainability actions. People often act when they see the efficacy of their responsible actions [180]. Incentives can be provided for engaging in responsible behaviors, and rewards can enhance customer delight.

Hypothesis 6 was supported. Our findings show that customer social responsibility is significant and positively related to customer satisfaction $(\beta=0.869 ; t=12.430 ; p<0.001)$. This is consistent with previous research (e.g., Luo and Bhattacharya, 2006), showing that customers' higher perceived value from firms' CSR activities acts as an antecedent to higher satisfaction from transacting with socially responsible companies. Scholars, for example $[134,147,149]$ argue that CSR performance influences consumers' satisfaction and organizational CSR creates a positive impact on customer satisfaction [150]. On the other hand, employees' CSR can enhance the quality of customer interaction at its functional level. The subtle implication is that being socially responsible may lead to superior quality perceptions. This would suggest that where visitors voluntarily engage in socially responsible behavior, they would expect to receive superior service delivery. This would establish a win-win situation.

Hypothesis 7 was supported, the relationship between customer social responsibility and customer delight was significant and positive $(B=0.299 ; t=4.842 ; p<0.001)$. Customers of $L U X^{*}$ are willing to be socially responsible to the extent that this maintains the convenience and enhances delight. There may be several explanations for this. First visitors wish to comply with generally acceptable behaviors for their benefit and for the benefit of other visitors. Visitors wish to maintain the reputation of the resort potentially to talk about it to friends and relatives. This corroborates with [112] who imply that the fit between a company and CSR activities exerts an authentic effect on corporate image. The fit between consumers' social responsibility expectations and firms' CSR activities may build potentially enduring customer relationships. Customers may also be willing to be socially responsible as they believe they are receiving value for money and have a positive evaluation of the resort enhancing customer delight [49].

\section{Implications}

\subsection{Implications for Hotels and Resort Managers}

An important process for hotels and resorts is to make CSR activities as visible as possible through signposting and advertising. Consumers need to able to readily access and verify the CSR information. For example, beach reclamation is a significant issue in many island states, it is important for hotels and resorts to establish a comprehensive understanding of CSR practices set to avoid negative effects of any change to the system. Consumers can make an informed decision based on their interpretations of the organizations' CSR performance and their willingness to pay a higher premium for CSR products [181]. It is recommended that CSR includes activities such as letting grass and flowers grow and using recycled water in gardening, to maintain biodiversity and protect environmental resources. Organizations need to visibly show employees' participation in these activities. Hotels and resorts could have a gardening site employee who encourage guests to actively engage in some fun, and creative low pro-environmental [84] gardening activities e.g., assisting staff in removal of weeds and raising beds for planting, watering plants at the hotel. Specific messages could also be set up across specific garden sites on the hotel premises to encourage participation. Effective communication can increase pro-environmental behavior compliance.

Organizations need to further explore local stakeholders to further support their CSR policies. Examples could include supporting the local community through sponsoring sports and education encouraging their employees and also those outside the organization to participate. Communicating about the projects through newsletters, displays and other channels will build awareness both locally and can also serve as an action for other organizations. Employees can be incentivized through recognition and bonuses for their continued commitment in encouraging and promoting CSR. Food 
waste is an important issue in hospitality organizations [182]. Restaurants in hotels and resorts generally tend to serve more food that customers will eat. Hotels and resorts can incentivize desirable behaviors such as free breakfast, lunch or dinner buffets for long-stay customers. We note that a lot of food in these feeding episodes is wasted, the actual financial cost of these incentives is small.

\subsection{Implications for Academics}

CSR has many similarities with sustainability, some discuss these terms as synonyms while others as two distinct concepts with the former focusing on social and the latter on environmental issues $[183,184]$. Synthesis and characterization of CSR still demands further work in the literature. Companies can be firm-oriented (serving interests of the organization) or public-serving [185]. CSR has been often a matter of perception rather than fact with fragmented discourses in the literature [181]. We argue that organizations can be financially, socially and environmentally sustainable. Our hope is to provoke further thinking and discussion among scholars and academics on how we can achieve financial, social and environmental goals synergistically. This may further allow for multi-stakeholder engagement for a common purpose, aligning with the UN Sustainable Development Goals [87]. Academic engagement with the hospitality sector is key and is now becoming increasingly important to cope with the immediate and plan for post-COVID-19 era [80].

\subsection{Implications for Policy Makers}

Our work is a considerable effort to highlight the need for a multi-stakeholder participatory approach for consistency and practicality. CSR can strengthen exchanges and communication and bring policy reforms. Government and private sector and local community participation are required in island tourism to reduce pollution of beaches and beach erosion, enhance biodiversity and promote social inclusivity to meet sustainable development goals. CSR can promote community support with further attention dedicated to the employee gender imbalance in the hospitality sector $[179,186]$.

\section{Conclusions and Suggestions for Future Research}

An important remark is that our study was conducted in a pre-COVID-19 context. Since the start of the global health pandemic, there has been significant changes in tourist numbers due to travel restrictions imposed by many nations across the globe. SARS-COV-2 has had important implications for the travel and tourism businesses globally. As businesses start to re-open in some destinations, the need for sustainable business models and practices is being increasingly recognized. Our findings will be even more important in the post pandemic context to encourage businesses to further align employees' and customers' expectations to promote sustainable tourism development hence collectively contributing to the sustainable development goals.

Organizational corporate social responsibility managers can build on our study's findings to promote pro-sustainable cultures across management, employees and customers and hence contribute to achieving a better and more responsible society and contribute to planetary health. Our model has been tested in developing island states of the Indian Ocean. Future researchers are encouraged to replicate the study in other island destinations such as the Caribbean and the Pacific, this would have important implications for sustainable tourism development in small island developing states. The present study was conducted in a five-star group of hotels. Future researchers can test the model across different star-rating hotels to shed further light on the interactions of the relationships.

Supplementary Materials: The following are available online at http://www.mdpi.com/2071-1050/12/22/9745/s1.

Author Contributions: Conceptualization, H.R. and F.M.; methodology, F.M., H.R. and V.S.; software, F.M., H.R. and V.S.; validation, F.M., H.R. and V.S.; formal analysis, H.R. and F.M. investigation, H.R., F.M. and V.S.; resources, H.R., F.M. and V.S.; data curation, H.R., F.M. and V.S.; writing-original draft preparation, H.R., F.M. and V.S.; writing-review and editing, H.R. and F.M.; visualization, H.R. and F.M.; supervision, H.R. and F.M. All authors have read and agreed to the published version of the manuscript.

Funding: This research received no external funding. 
Conflicts of Interest: The authors declare no conflict of interest.

\section{References}

1. UNWTO Annual Report 2016. Available online: https://www.e-unwto.org/doi/book/10.18111/9789284418725 (accessed on 1 May 2019).

2. United Nations Summit on Sustainable Development 2015, Informal Summary. Available online: https://sustainabledevelopment.un.org/content/documents/8521Informal\%20Summary\%20-\%20UN\% 20Summit\%20on\%20Sustainable\%20Development\%202015.pdf (accessed on 1 May 2019).

3. Hristov, D.; Ramkissoon, H. Leadership in destination management organisations. Ann. Tour. Res. 2016, 61, 230-234. [CrossRef]

4. Scheyvens, R.; Biddulph, R. Inclusive tourism development. Tour. Geogr. 2018, 20, 589-609. [CrossRef]

5. He, H.; Harris, L. The Impact of Covid-19 Pandemic on Corporate Social Responsibility and Marketing Philosophy. J. Bus Res. 2020, 116, 176-182. [CrossRef] [PubMed]

6. Scheyvens, R.; Banks, G.; Hughes, E. The private sector and the SDGs: The need to move beyond 'business as usual'. Sust. Dev. 2016, 24, 371-382. [CrossRef]

7. Saarinen, J.; Rogerson, C.M. Tourism and the millennium development goals: Perspectives beyond 2015. Tour Geog. 2014, 16, 23-30. [CrossRef]

8. Ineson, E.M.; Benke, E.; László, J. Employee loyalty in Hungarian hotels. Int. J. Hosp. Man. 2013, 32, 31-39. [CrossRef]

9. Zhao, X.R.; Mattila, A.S. Examining the spillover effect of frontline employees' work-family conflict on their affective work attitudes and customer satisfaction. Int. J. Hosp. Manag. 2013, 33, 310-315. [CrossRef]

10. Deery, M.; Jago, L. A framework for work-life balance practices: Addressing the needs of the tourism industry. Tour. Hosp. Res. 2009, 9, 97-108. [CrossRef]

11. Lawson, K.M.; Davis, K.D.; Crouter, A.C.; O'Neill, J.W. Understanding work-family spillover in hotel managers. Int. J. Hosp. Manag. 2013, 33, 273-281. [CrossRef]

12. Lashley, C. Costing staff turnover in hospitality service organisations. J. Serv Res. 2001, 1, 3-24.

13. Mayer, A.E. Human Rights as a Dimension of CSR: The Blurred Lines Between Legal and Non-Legal Categories. J. Bus. Ethic- 2009, 88, 561-577. [CrossRef]

14. Sanjeev, G.M.; Birdie, A.K. The tourism and hospitality industry in India: Emerging issues for the next decade. Worldw. Hosp. Tour. Themes 2019, 11, 355-361. [CrossRef]

15. Sen, K.; Bhattacharya, A. Attracting and managing talent, how are the top three hotel companies in India doing it? Worldw. Hosp. Tour. Themes 2019, 11, 404-417. [CrossRef]

16. Coles, T.; Fenclova, E.; Dinan, C. Tourism and corporate social responsibility: A critical review and research agenda. Tour. Manag. Perspect. 2013, 6, 122-141. [CrossRef]

17. Font, X.; Lynes, J. Corporate social responsibility in tourism and hospitality. J. Sustain. Tour. 2018, 26, 1027-1042. [CrossRef]

18. Baniya, R.; Rajak, K. Attitude, Motivation and barriers for csr engagement among travel and tour operators in Nepal. J. Tour. Hosp. Educ. 2020, 10, 53-70. [CrossRef]

19. Jamali, D.; Lund-Thomsen, P.; Jeppesen, S. SMEs and CSR in developing countries. Bus. Soc. 2017, 56, 11-22. [CrossRef]

20. El-Kassar, A.N.; Messarra, L.C.; El-Khalil, R. CSR, organizational identification, normative commitment, and the moderating effect of the importance of CSR. J. Dev. Areas 2017, 51, 409-424. [CrossRef]

21. Way, S.A.; Sturman, M.C.; Raab, C. What matters more? Cornell Hosp. Q. 2010, 51, 379-397. [CrossRef]

22. Bakker, A.B.; Albrecht, S.L.; Leiter, M.P. Key questions regarding work engagement. Eur. J. Work. Organ. Psychol. 2011, 20, 4-28. [CrossRef]

23. Epstein, M.J.; Roy, M.J. Sustainability in action: Identifying and measuring the key performance drivers. Long Range Plan. 2001, 34, 585-604. [CrossRef]

24. Crouch, C. CSR and Changing Modes of governance: Towards corporate noblesse oblige? In Corporate Social Responsibility and Regulatory Governance; Utting, P., Marques, J.C., Eds.; Palgrave Macmillan: London, UK, 2010; pp. 26-49. 
25. Sowamber, V.; Ramkissoon, H.; Mavondo, F. Impact of sustainability practices on hospitality consumers' behaviors and attitudes: The case of LUX* Resorts \& Hotels. In Routledge Handbook of Hospitality Marketing; Routledge: Abingdon, UK, 2017; pp. 384-396.

26. Dewnarain, S.; Ramkissoon, H.; Mavondo, F. Social customer relationship management in the hospitality industry. J. Hosp. 2019, 1, 1-14.

27. Bhattacharya, C.B.; Sen, S.; Korschun, D. Using corporate social responsibility to win the war for talent. MIT Sloan Manag. Rev. 2008, 49, 37-44.

28. Ramkissoon, H.; Sowamber, V. Local support in tourism in Mauritius. In Routledge Handbook of Tourism in Africa; Novelli, M., Adu-Among, M.E., Ribeiro, A., Eds.; Routledge: London, UK, 2020.

29. Torelli, R.; Balluchi, F.; Furlotti, K. The materiality assessment and stakeholder engagement: A content analysis of sustainability reports. Corp. Soc. Responsib. Environ. Manag. 2020, 27, 470-484. [CrossRef]

30. Baird, T.; Hall, C.M.; Castka, P.; Ramkissoon, H. Migrant Workers' Rights, Social Justice and Sustainability in Australian and New Zealand Wineries: A Comparative Context. In Social Sustainability in the Global Wine Industry; Palgrave Pivot: Cham, Switzerland, 2020; pp. 107-118.

31. Levy, S.E.; Park, S.-Y. An analysis of CSR activities in the lodging industry. J. Hosp. Tour. Manag. 2011, 18, 147-154. [CrossRef]

32. He, H.; Li, Y. CSR and service brand: The mediating effect of brand identification and moderating effect of service quality. J. Bus. Ethics 2011, 100, 673-688. [CrossRef]

33. Marin, L.; Ruiz, S.; Rubio, A. The role of identity salience in the effects of corporate social responsibility on consumer behavior. J. Bus. Ethics 2009, 84, 65-78. [CrossRef]

34. Gardberg, N.A.; Fombrun, C.J. Corporate citizenship: Creating intangible assets across institutional environments. Acad. Manag. Rev. 2006, 31, 329-346. [CrossRef]

35. Bello, F.G.; Kamanga, G. Drivers and barriers of corporate social responsibility in the tourism industry: The case of Malawi. Dev. South. Afr. 2020, 37, 181-196. [CrossRef]

36. Thompson, B.S.; Friess, D.A. Stakeholder preferences for payments for ecosystem services (PES) versus other environmental management approaches for mangrove forests. J. Environ. Manag. 2019, 233, 636-648. [CrossRef]

37. Strasdas, W. Corporate Responsibility among international ecotourism and adventure travel operators. In Corporate Sustainability and Responsibility in Tourism; Lund-Durlacher, D., Dinica, V., Reiser, D., Fifka, M., Eds.; Springer: Cham, Switzerland, 2019; pp. 143-161.

38. Iazzi, A.; Pizzi, S.; Iaia, L.; Turco, M. Communicating the stakeholder engagement process: A cross-country analysis in the tourism sector. Corp. Soc. Responsib. Environ. Manag. 2020, 27, 1642-1652. [CrossRef]

39. Bickford, N.; Smith, L.; Bickford, S.; Bice, M.R. Evaluating the role of CSR and SLO in ecotourism: Collaboration for economic and environmental sustainability of arctic resources. Resources 2017, 6, 21. [CrossRef]

40. Sheldon, P.J.; Park, S.Y. An exploratory study of corporate social responsibility in the US travel industry. J. Travel Res. 2011, 50, 392-407. [CrossRef]

41. Supanti, D.; Butcher, K.; Fredline, L. Enhancing the employer-employee relationship through corporate social responsibility (CSR) engagement. Int. J. Contemp. Hosp. Manag. 2015, 27, 1479-1498. [CrossRef]

42. Wells, V.K.; Manika, D.; Gregory-Smith, D.; Taheri, B.; McCowlen, C. Heritage tourism, CSR and the role of employee environmental behaviour. Tour. Manag. 2015, 48, 399-413. [CrossRef]

43. Jones, P.; Hillier, D.; Comfort, D. Sustainability in the hospitality industry. Int. J. Contemp. Hosp. Manag. 2016, 28, 36-67. [CrossRef]

44. Modica, P.D.; Altinay, L.; Farmaki, A.; Gursoy, D.; Zenga, M. Consumer perceptions towards sustainable supply chain practices in the hospitality industry. Curr. Issues Tour. 2020, 23, 358-375. [CrossRef]

45. Chathoth, P.K.; Ungson, G.R.; Harrington, R.J.; Chan, E.S. Co-creation and higher order customer engagement in hospitality and tourism services. Int. J. Contemp. Hosp. Manag. 2016, 28, 222. [CrossRef]

46. Okumus, F.; Altinay, L.; Chathoth, P.; Koseoglu, M.A. Strategic Management for Hospitality and Tourism; Routledge: Abingdon, UK, 2019.

47. Camilleri, M.A. Advancing the sustainable tourism agenda through strategic CSR perspectives. Tour. Plan. Dev. 2014, 11, 42-56. [CrossRef]

48. Homburg, C.; Wieseke, J.; Hoyer, W.D. Social identity and the service-profit chain. J. Mark. 2009, 73, 38-54. [CrossRef] 
49. Jiang, Y.; Ramkissoon, H.; Mavondo, F. Destination marketing and visitor experiences: The development of a conceptual framework. J. Hosp. Mark. Manag. 2016, 25, 653-675. [CrossRef]

50. Ramkissoon, H. Hospitality consumers' decision-making. In Routledge Handbook of Hospitality Marketing; Routledge: Abingdon, UK, 2018; pp. 271-283.

51. Barakat, S.R.; Isabella, G.; Boaventura, J.M.G.; Mazzon, J.A. The influence of corporate social responsibility on employee satisfaction. Manag. Decis. 2016, 54, 2325-2339. [CrossRef]

52. Bauman, C.W.; Skitka, L.J. Corporate social responsibility as a source of employee satisfaction. Res. Organ. Behav. 2012, 32, 63-86. [CrossRef]

53. Dögl, C.; Holtbrügge, D. Corporate environmental responsibility, employer reputation and employee commitment: An empirical study in developed and emerging economies. Int. J. Hum. Resour. Manag. 2014, 25, 1739-1762. [CrossRef]

54. Wong, I.A.; Gao, J.H. Exploring the direct and indirect effects of CSR on organizational commitment. Int. J. Contemp. Hosp. Manag. 2014, 26, 500-525. [CrossRef]

55. Du, S.; Bhattacharya, C.; Sen, S. Reaping relational rewards from corporate social responsibility: The role of competitive positioning. Int. J. Res. Mark. 2007, 24, 224-241. [CrossRef]

56. Wang, Y.; Xu, S.; Wang, Y. The consequences of employees' perceived corporate social responsibility: A meta-analysis. Bus. Ethic- A Eur. Rev. 2020, 29, 471-496. [CrossRef]

57. Wagner, T.; Lutz, R.J.; Weitz, B.A. Corporate Hypocrisy: Overcoming the Threat of Inconsistent Corporate Social Responsibility Perceptions. J. Mark. 2009, 73, 77-91. [CrossRef]

58. Walker, M.; Heere, B.; Parent, M.M.; Drane, D. Social responsibility and the olympic games: The Mediating role of consumer attributions. J. Bus. Ethics 2010, 95, 659-680. [CrossRef]

59. Peasley, M.C.; Woodroof, P.J.; Coleman, J.T. Processing contradictory CSR information: The influence of primacy and recency effects on the consumer-firm relationship. J. Bus. Ethics 2020,1-15. [CrossRef]

60. Rim, H.; Park, Y.E.; Song, D. Watch out when expectancy is violated: An experiment of inconsistent CSR message cueing. J. Mark. Commun. 2020, 26, 343-361. [CrossRef]

61. Hillenbrand, C.; Money, K.; Ghobadian, A. Unpacking the mechanism by which corporate responsibility impacts stakeholder relationships. Br. J. Manag. 2011, 24, 127-146. [CrossRef]

62. Fishbein, M. A theory of reasoned action: Some applications and implications. Neb. Symp. Motiv. 1979, 27, 65-116.

63. Ajzen, I. Attitudes, Personality and Behaviour; Open University Press: Milton Keynes, UK, 1988.

64. Alam, S.S.; Akter, S.; Ahmed, M.H.U. Explaining firms' behavioral intention towards environmental reporting in Bangladesh: An application of theory of planned behavior. J. Int. Bus. Manag. 2020, 3, 1-12. [CrossRef]

65. Darus, F.; Sawani, Y.; Zain, M.M.; Janggu, T. Impediments to CSR assurance in an emerging economy. Manag. Audit. J. 2014, 29, 253. [CrossRef]

66. Brammer, S.; Millington, A.; Rayton, B. The contribution of corporate social responsibility to organizational commitment. Int. J. Hum. Resour. Manag. 2007, 18, 1701-1719. [CrossRef]

67. Peterson, D.K. The relationship between perceptions of corporate citizenship and organizational commitment. Bus. Soc. 2004, 43, 296-319. [CrossRef]

68. Hogg, M.A. Social identity theory. In Understanding Peace and Conflict through Social Identity Theory; Springer: Cham, Switzerland, 2016; pp. 3-17.

69. Dube, K.; Nhamo, G. Vulnerability of nature-based tourism to climate variability and change: Case of Kariba resort town, Zimbabwe. J. Outdoor Recreat. Tour. 2020, 29, 100281. [CrossRef]

70. Scott, D.; Hall, C.M.; Gössling, S. A review of the IPCC Fifth assessment and implications for tourism sector climate resilience and decarbonization. J. Sustain. Tour. 2016, 24, 8-30. [CrossRef]

71. Rutty, M.; Gössling, S.; Scott, D.; Michael Hall, C. The global effects and impacts of tourism. In The Routledge Handbook of Tourism and Sustainability; Rutty, M., Gössling, S., Scott, D., Michael Hall, C., Eds.; Routledge: London, UK, 2015; pp. 36-62.

72. Scott, D.; Gössling, S.; Hall, C.M. International tourism and climate change. Wiley Interdiscip. Rev. Clim. Chang. 2012, 3, 213-232. [CrossRef]

73. UNWTO Annual Report. 2015. Available online: https://www.e-unwto.org/doi/pdf/10.18111/9789284418039 (accessed on 2 May 2019).

74. McCabe, S. The Routledge Handbook of Tourism Marketing; Routledge: London, UK, 2014. 
75. Ramkissoon, H.; Smith LD, G.; Weiler, B. Testing the dimensionality of place attachment and its relationships with place satisfaction and pro-environmental behaviours: A structural equation modelling approach. Tour. Manag. 2013, 36, 552-566. [CrossRef]

76. Gössling, S.; Scott, D.; Hall, C.M. Pandemics, tourism and global change: A rapid assessment of COVID-19. J. Sustain. Tour. 2020, 29, 1-20. [CrossRef]

77. Scott, D.; Gössling, S.; Hall, C.M.; Peeters, P. Can tourism be part of the decarbonized global economy? The costs and risks of alternate carbon reduction policy pathways. J. Sustain. Tour. 2015, 24, 1-21. [CrossRef]

78. United Nations Environment Programme (UNEP) Report 2015. Available online: https://www. unenvironment.org/annualreport/2015/en/index.html (accessed on 14 May 2019).

79. MET Report 2017. Available online: https://www.metoffice.gov.uk/research/news/2018/annual-state-of-theclimate-report-for-2017-now-published (accessed on 5 May 2019).

80. Majeed, S.; Ramkissoon, H. Health, wellness and place attachment during and post health pandemics. Front. Psychol. 2020, 11, 3026.

81. Higgins-Desbiolles, F. Socialising tourism for social and ecological justice after COVID-19. Tour. Geogr. 2020, 22, 610-623. [CrossRef]

82. Nunkoo, R.; Ramkissoon, H. Stakeholders' views of enclave tourism: A grounded theory approach. J. Hosp. Tour. Res. 2016, 40, 557-558. [CrossRef]

83. Hristov, D.; Minocha, S.; Ramkissoon, H. Transformation of destination leadership networks. Tour. Manag. Perspect. 2018, 28, 239-250. [CrossRef]

84. Ramkissoon, H.; Mavondo, F.T. Pro-environmental behavior: Critical link between satisfaction and place attachment in Australia and Canada. Tour. Anal. 2017, 22, 59-73. [CrossRef]

85. Xu, S.; Li, Y. Beware of the second wave of COVID-19. Lancet 2020, 395, 1321-1322. [CrossRef]

86. Wymer, W.; Polonsky, M.J. The limitations and potentialities of green marketing. J. Nonprofit Public Sect. Mark. 2015, 27, 239-262. [CrossRef]

87. Ramkissoon, H. COVID-19 Place confinement, pro-social, pro-environmental behaviors, and residents' wellbeing: A new conceptual framework. Front. Psychol. 2020, 11, 2248. [CrossRef] [PubMed]

88. Kotler, P.; Lee, N. Social Marketing: Influencing Behaviors for Good; Sage Publications: Thousand Oaks, CA, USA, 2008.

89. Truong, V.D. Social marketing: A systematic review of research 1998-2012. Soc. Mark. Q. 2014, 20, 15-34. [CrossRef]

90. Truong, V.D.; Dang, N.V.; Hall, C.M.; Dong, X.D. The internationalisation of social marketing research. J. Soc. Mark. 2015, 5, 357-376. [CrossRef]

91. De Grosbois, D. Corporate social responsibility reporting by the global hotel industry: Commitment, initiatives and performance. Int. J. Contemp. Hosp. Manag. 2012, 31, 896-905. [CrossRef]

92. Dodds, R.; Joppe, M. CSR in the Tourism Industry? The Status of and Potential for Certification, Codes of Conduct and Guidelines; IFC: Washington, DC, USA, 2005.

93. Uduji, J.I.; Okolo-Obasi, E.N.; Asongu, S.A. Sustaining cultural tourism through higher female participation in Nigeria: The role of corporate social responsibility in oil host communities. Int. J. Tour. Res. 2020, 22, 120-143. [CrossRef]

94. Font, X.; Walmsley, A.; Cogotti, S.; McCombes, L.; Häusler, N. Corporate social responsibility: The disclosure-performance gap. Tour. Manag. 2012, 33, 1544-1553. [CrossRef]

95. Tsai, H.; Tsang, N.K.; Cheng, S.K. Hotel employees' perceptions on corporate social responsibility: The case of Hong Kong. Int. J. Hosp. Manag. 2012, 31, 1143-1154. [CrossRef]

96. Waddock, S.A.; Bodwell, C.; Graves, S.B. Responsibility: The new business imperative. Acad. Manag. Perspect. 2002, 16, 132-148. [CrossRef]

97. Andriof, J.; Waddock, S. Unfolding stakeholder engagement. In Unfolding Stakeholder Thinking; Routledge: Abingdon, UK, 2017; pp. 19-42.

98. Ramkissoon, H.; Mavondo, F.T. Managing customer relationships in hotel chains: A comparison between guest and manager perceptions. In The Routledge Handbook of Hotel Chain Management; Routledge: Abingdon, UK, 2016; pp. 295-304.

99. Chiang, C.F.; Jang, S.S. The antecedents and consequences of psychological empowerment: The case of Taiwan's hotel companies. J. Hosp. Tour. Res. 2008, 32, 40-61. [CrossRef] 
100. Park, S.Y.; Levy, S. Corporate social responsibility: Perspectives of hotel frontline employees. Int. J. Contemp. Hosp. Manag. 2014, 26, 332-348. [CrossRef]

101. Choi, B.; La, S. The impact of corporate social responsibility (CSR) and customer trust on the restoration of loyalty after service failure and recovery. J. Serv. Mark. 2013, 27, 223-233. [CrossRef]

102. Carroll, A.B.; Laasch, O. From managerial responsibility to CSR and back to responsible management. In The Research Handbook of Responsible Management; Edward Elgar: Cheltenham, UK, 2020.

103. Kim, C.H.; Scullion, H. The effect of Corporate Social Responsibility (CSR) on employee motivation: A cross-national study. Pozn. Univ. Econ. Rev. 2013, 13, 5-30.

104. Schaefer, S.D.; Terlutter, R.; Diehl, S. Talking about CSR matters: Employees' perception of and reaction to their company's CSR communication in four different CSR domains. Int. J. Advert. 2020, 39, 191-212. [CrossRef]

105. Lee, E.M.; Park, S.Y.; Lee, H.J. Employee perception of CSR activities: Its antecedents and consequences. J. Bus. Res. 2013, 66, 1716-1724. [CrossRef]

106. Ramkissoon, H.; Mavondo, F.; Uysal, M. Social involvement and park citizenship as moderators for quality-of-life in a national park. J. Sustain. Tour. 2018, 26, 341-361. [CrossRef]

107. Tingchi Liu, M.; Anthony Wong, I.; Rongwei, C.; Tseng, T.H. Do perceived CSR initiatives enhance customer preference and loyalty in casinos? Int. J. Contemp. Hosp. Manag. 2014, 26, 1024-1045. [CrossRef]

108. Becker-Olsen, K.L.; Cudmore, B.A.; Hill, R.P. The impact of perceived corporate social responsibility on consumer behavior. J. Bus. Res. 2006, 59, 46-53. [CrossRef]

109. Carvalho, S.W.; Sen, S.; Mota, M.D.O.; De Lima, R.C. Consumer reactions to CSR: A Brazilian perspective. J. Bus. Ethic- 2010, 91, 291-310. [CrossRef]

110. Lee, S.; Park, S.-Y. Do socially responsible activities help hotels and casinos achieve their financial goals? Int. J. Hosp. Manag. 2009, 28, 105-112. [CrossRef]

111. Tajfel, H.; Turner, J.C. The social identity theory of intergroup behavior. In Psychology of Intergroup Relations; Worchel, S., Austin, W.G., Eds.; Nelson-Hall Publishers: Chicago, IL, USA, 1986; pp. 7-24.

112. Kim, H.R.; Lee, M.; Lee, H.T.; Kim, N.M. Corporate social responsibility and employee-company identification. J. Bus. Ethics 2010, 95, 557-569. [CrossRef]

113. Hess, D.; Ford, C.L. Corporate corruption and reform undertakings: A new approach to an old problem. Cornell Int. Law J. 2008, 41, 307.

114. Albus, H.; Ro, H. Corporate social responsibility: The effect of green practices in a service recovery. J. Hosp. Tour. Res. 2013. [CrossRef]

115. Pérez, A.; Del Bosque, I.R. Measuring CSR image: Three studies to develop and to validate a reliable measurement tool. J. Bus. Ethic- 2013, 118, 265-286. [CrossRef]

116. Pirsch, J.; Gupta, S.; Grau, S.L. A framework for understanding corporate social responsibility programs as a continuum: An exploratory study. J. Bus. Ethics 2007, 70, 125-140. [CrossRef]

117. Karatepe, O.M. High-performance work practices and hotel employee performance: The mediation of work engagement. Int. J. Hosp. Manag. 2013, 32, 132-140. [CrossRef]

118. Salanova, M.; Agut, S.; Peiró, J.M. Linking organizational resources and work engagement to employee performance and customer loyalty: The mediation of service climate. J. Appl. Psychol. 2005, 90, 1217-1227. [CrossRef]

119. Deng, X.; Kang, J.-K.; Low, B.S. Corporate social responsibility and stakeholder value maximization: Evidence from mergers. J. Financial Econ. 2013, 110, 87-109. [CrossRef]

120. Oliver, C. Sustainable competitive advantage: Combining institutional and resource-based views. Strateg. Manag. J. 1997, 8, 697-713. [CrossRef]

121. Turker, D. Measuring corporate social responsibility: A scale development study. J. Bus. Ethics 2009, 85, 411-427. [CrossRef]

122. Epler Wood, M.; Leray, T. Corporate Responsibility and the Tourism Sector in Cambodia; Working Paper, No. 34658; World Bank Group: Washington, DC, USA, 2005; p. 1.

123. Ketola, T. Do you trust your boss?-A Jungian analysis of leadership reliability in CSR. Electron. J. Bus. Ethics Organ. Stud. 2006, 11, 6-14.

124. Idemudia, U. Corporate social responsibility and developing countries. Prog. Dev. Stud. 2011, 11, 1-18. [CrossRef] 
125. Levy, S.E.; Hawkins, D.E. Peace through tourism: Commerce based principles and practices. J. Bus. Ethic2009, 89, 569-585. [CrossRef]

126. Kalisch, A. Corporate Futures: Social Responsibility in the Tourism Industry; Consultation On Good Practice; Tourism Concern: London, UK, 2002.

127. Lin, L.W. Corporate social responsibility in China: Window dressing or structural change. Berkeley J. Int. Law 2010, 28, 64. [CrossRef]

128. Cacioppe, R.; Forster, N.; Fox, M. A survey of managers' perceptions of corporate ethics and social responsibility and actions that may affect companies' success. J. Bus. Ethic- 2007, 82, 681-700. [CrossRef]

129. Ashley, C.; Haysom, G. From philanthropy to a different way of doing business: Strategies and challenges in integrating pro-poor approaches into tourism business. Dev. South. Afr. 2006, 23, 265-280. [CrossRef]

130. Barroso Castro, C.; Martín Armario, E.; Martín Ruiz, D. The influence of employee organizational citizenship behavior on customer loyalty. Int. J. Serv. Ind. Manag. 2004, 15, 27-53. [CrossRef]

131. Mackenzie, M.; Peters, M. Hospitality managers' perception of corporate social responsibility: An explorative study. Asia Pac. J. Tour. Res. 2014, 19, 257-272. [CrossRef]

132. Greening, D.W.; Turban, D.B. Corporate social performance as a competitive advantage in attracting a quality workforce. Bus. Soc. 2000, 39, 254-280. [CrossRef]

133. Rupp, D.E.; Ganapathi, J.; Aguilera, R.V.; Williams, C.A. Employee reactions to corporate social responsibility: An organizational justice framework. J. Organ. Behav. 2006, 27, 537-543. [CrossRef]

134. Korschun, D.; Bhattacharya, C.; Swain, S.D. Corporate social responsibility, customer orientation, and the job performance of frontline employees. J. Mark. 2014, 78, 20-37. [CrossRef]

135. Bartel, C.A. Social comparisons in boundary-spanning work: Effects of community outreach on members' organizational identity and identification. Adm. Sci. Q. 2001, 46, 379-413. [CrossRef]

136. Luo, X.; Bhattacharya, C.B. Corporate social responsibility, customer satisfaction, and market value. J. Mark. 2006, 70, 1-18. [CrossRef]

137. Sen, S.; Bhattacharya, C.B. Does doing good always lead to doing better? Consumer reactions to corporate social responsibility. J. Mark. Res. 2001, 38, 225-243. [CrossRef]

138. Lichtenstein, D.R.; Drumwright, M.E.; Braig, B.M. The effect of corporate social responsibility on customer donations to corporate-supported nonprofits. J. Mark. 2004, 68, 16-32. [CrossRef]

139. Bhattacharya, C.B.; Sen, S. Consumer-company identification: A framework for understanding consumers' relationships with companies. J. Mark. 2003, 67, 76-88. [CrossRef]

140. Dewnarain, S.; Ramkissoon, H.; Mavondo, F. Social customer relationship management: An integrated conceptual framework. J. Hosp. Mark. Manag. 2019, 28, 172-188. [CrossRef]

141. Makower, J. Beyond the Bottom Line; Simon: New York, NY, USA, 1994.

142. Wilson, A.; Zeithaml, V.; Bitner, M.J.; Gremler, D. Services Marketing: Integrating Customer Focus across the Firm; McGraw-Hill Education: London, UK, 2016.

143. McKercher, B.; Mackenzie, M.; Prideaux, B.; Pang, S. Is the hospitality and tourism curriculum effective in teaching personal social responsibility? J. Hosp. Tour. Res. 2012. [CrossRef]

144. Soron, D. Sustainability, self-identity and the sociology of consumption. Sustain. Dev. 2010, 18, $172-181$. [CrossRef]

145. Brown, T.J.; Mowen, J.C.; Donavan, D.T.; Licata, J.W. The Customer Orientation of Service Workers: Personality Trait Effects on Self-and Supervisor Performance Ratings. J. Mark. Res. 2002, 39, 110-119. [CrossRef]

146. Hemingway, C.A.; Maclagan, P.W. Managers' personal values as drivers of corporate social responsibility. J. Bus. Ethics 2004, 50, 33-44. [CrossRef]

147. Chi, C.G.; Gursoy, D. Employee satisfaction, customer satisfaction, and financial performance: An empirical examination. Int. J. Contemp. Hosp. Manag. 2009, 28, 245-253. [CrossRef]

148. Hartline, M.D.; Jones, K.C. Employee performance cues in a hotel service environment: Influence on perceived service quality, value, and word-of-mouth intentions. J. Bus. Res. 1996, 35, 207-215. [CrossRef]

149. Liao, H.; Chuang, A. A multilevel investigation of factors influencing employee service performance and customer outcomes. Acad. Manag. J. 2004, 47, 41-58.

150. Lee, S.; Heo, C.Y. Corporate social responsibility and customer satisfaction among US publicly traded hotels and restaurants. Int. J. Hosp. Manag. 2009, 28, 635-637. [CrossRef] 
151. Finn, A. Customer delight: Distinct construct or zone of nonlinear response to customer satisfaction? J. Serv. Res. 2012, 15, 99-110. [CrossRef]

152. Oliver, R.; Rust, R.; Varki, S. Customer delight: Foundations, findings, and managerial insight. J. Retail. 1997, 73, 311-336. [CrossRef]

153. Ramkissoon, H.; Mavondo, F. Proenvironmental behavior: The link between place attachment and place satisfaction. Tour. Anal. 2014, 19, 673-688. [CrossRef]

154. Torres, E.N.; Kline, S. From customer satisfaction to customer delight. Int. J. Contemp. Hosp. Manag. 2013, 25, 642-659. [CrossRef]

155. Torres, E.N.; Milman, A.; Park, S. Delighted or outraged? Uncovering key drivers of exceedingly positive and negative theme park guest experiences. J. Hosp. Tour. Insights 2018, 1, 65-85. [CrossRef]

156. Kumar, A.; Olshavsky, R.W.; King, M.F. Exploring alternative antecedents of customer delight. J. Consum. Satisf. Dissatisfaction Complain. Behav. 2001, 14, 14.

157. Crotts, J.C.; Magnini, V.P. The customer delight construct. Ann. Tour. Res. 2011, 38, 719-722. [CrossRef]

158. Fuller, J.; Matzler, K.; Faullant, R. Asymmetric effects in customer satisfaction. Ann. Tour. Res. 2006, 33, 1159-1163. [CrossRef]

159. Oliver, R.L. Cognitive, affective, and attribute bases of the satisfaction response. J. Consum. Res. 1993, 20, 418-430. [CrossRef]

160. Urry, J. The consumption of tourism. Sociology 1990, 24, 23-35. [CrossRef]

161. Nunkoo, R.; Ramkissoon, H. Developing a community support model for tourism. Ann. Tour. Res. 2011, 38, 964-988. [CrossRef]

162. Ramkissoon, H.; Uysal, M.S. The effects of perceived authenticity, information search behaviour, motivation and destination imagery on cultural behavioural intentions of tourists. Curr. Issues Tour. 2011, 14, 537-562. [CrossRef]

163. Nunkoo, R.; Smith, S.L.; Ramkissoon, H. Residents' attitudes to tourism: A longitudinal study of 140 articles from 1984 to 2010. J. Sustain. Tour. 2013, 21, 5-25. [CrossRef]

164. Akhshik, A.; Rezapouraghdam, H.; Ramkissoon, H. Industrialization of Nature in the Time of Complexity Unawareness: The Case of Chitgar Lake, Iran. J. Hosp. Tour. Res. 2020. [CrossRef]

165. Hair, J.F.; Black, W.C.; Babin, B.J.; Anderson, R.E. Multivariate Data Analysis; Prentice Hall: Upper Saddle River, NJ, USA, 2010.

166. Waddock, S. Parallel universes: Companies, academics, and the progress of corporate citizenship. Bus. Soc. Rev. 2004, 109, 5-42. [CrossRef]

167. Nunkoo, R.; Ramkissoon, H. Structural equation modelling and regression analysis in tourism research. Curr. Issues Tour. 2012, 15, 777-802. [CrossRef]

168. Ramkissoon, H.; Mavondo, F.T. The satisfaction-place attachment relationship: Potential mediators and moderators. J. Bus. Res. 2015, 68, 2593-2602. [CrossRef]

169. Nunkoo, R.; Ramkissoon, H.; Gursoy, D. Use of structural equation modeling in tourism research: Past, present, and future. J. Travel Res. 2013, 52, 759-771. [CrossRef]

170. Fornell, C.; Larcker, D.F. Evaluating structural equation models with unobservable variables and measurement error. J. Mark. Res. 1981, 28, 39-50. [CrossRef]

171. McDonald, R.P.; Ho, M.-H.R. Principles and practice in reporting structural equation analyses. Psychol. Methods 2002, 7, 64-82. [CrossRef] [PubMed]

172. Collier, J.; Esteban, R. Corporate social responsibility and employee commitment. Bus. Ethic- A Eur. Rev. 2007, 16, 19-33. [CrossRef]

173. Boccia, F.; Malgeri Manzo, R.; Covino, D. Consumer behavior and corporate social responsibility: An evaluation by a choice experiment. Corp. Soc. Responsib. Environ. Manag. 2019, 26, 97-105. [CrossRef]

174. Randle, M.; Kemperman, A.; Dolnicar, S. Making cause-related corporate social responsibility (CSR) count in holiday accommodation choice. Tour. Manag. 2019, 75, 66-77. [CrossRef]

175. Feldman, P.M.; Vasquez-Parraga, A.Z. Consumer social responses to CSR initiatives versus corporate abilities. J. Consum. Mark. 2013, 30, 100-111. [CrossRef]

176. Pomering, A.; Dolnicar, S. Assessing the prerequisite of successful CSR implementation: Are consumers aware of CSR initiatives? J. Bus. Ethic- 2009, 85, 285-301. [CrossRef]

177. Perks, K.J.; Farache, F.; Shukla, P.; Berry, A. Communicating responsibility-practicing irresponsibility in CSR advertisements. J. Bus. Res. 2013, 66, 1881-1888. [CrossRef] 
178. Öberseder, M.; Schlegelmilch, B.B.; Murphy, P.E. CSR practices and consumer perceptions. J. Bus. Res. 2013, 66, 1839-1851. [CrossRef]

179. Nunkoo, R.; Ramkissoon, H. Gendered theory of planned behaviour and residents' support for tourism. Curr. Issues Tour. 2010, 13, 525-540. [CrossRef]

180. Ramkissoon, H.R.; Smith LD, G. The relationship between environmental worldviews, emotions and personal efficacy in climate change. Int. J. Arts Sci. 2014, 7, 93.

181. Pope, S.; Wæraas, A. CSR-washing is rare: A conceptual framework, literature review, and critique. J. Bus. Ethics 2016, 137, 173-193. [CrossRef]

182. Chen, H.S.; Jai, T.M. Waste less, enjoy more: Forming a messaging campaign and reducing food waste in restaurants. J. Qual. Assur. Hosp. Tour. 2018, 19, 495-520. [CrossRef]

183. Schwartz, M.S.; Carroll, A.B. Integrating and unifying competing and complementary frameworks: The search for a common core in the business and society field. Bus. Soc. 2008, 47, 148-186. [CrossRef]

184. Strand, R.; Freeman, R.E.; Hockerts, K. Corporate social responsibility and sustainability in Scandinavia: An overview. J. Bus. Ethics 2015, 127, 1-15. [CrossRef]

185. Austin, L.; Gaither, B.M. Perceived motivations for corporate social responsibility initiatives in socially stigmatized industries. Public Relat. Rev. 2017, 43, 840-849. [CrossRef]

186. Spence, L.J. The obfuscation of gender and feminism in CSR research and the academic community: An essay. In Gender Equality and Responsible Business; Routledge: Abingdon, UK, 2017; pp. 16-30.

Publisher's Note: MDPI stays neutral with regard to jurisdictional claims in published maps and institutional affiliations. 